\title{
Diagnostic value of the integral assessment of electroencephalographic pattern in patients in the acute period of spontaneous supratentorial intracerebral hemorrhage
}

\author{
A. A. Kuznietsov \\ Zaporizhzhia State Medical University, Ukraine
}

Key words:

cerebral

hemorrhage,

electroencephalo-

graphy,

X-Ray tomography.

Pathologia

2018; 15 (3), 378-385

DOl:

10.14739/2310-1237

2018.3.151869

E-mail:

titus3.05@gmail.com

The main purpose of the study was to verify the diagnostic informative value of the integral evaluation of the electroencephalographic pattern in patients with spontaneous supratentorial intracerebral hemorrhage (SSICH) on the basis of the comparison of brain activity changes with clinical and neuroimaging data.

Material and methods. Prospective cohort study of 46 patients in acute period of SSICH was conducted. It included complex clinical (using Glasgow Coma Scale, Full Outline of UnResponsiveness (FOUR) score, National Institute of Health Stroke Scale, Intracerebral hemorrhage score) and neuroimaging estimation of cerebral injury severity in the onset of the disease. Investigation of brain bioelectrical activity was made during first 24-48 hours from the onset with determination of average absolute spectral rhythm power (AASRP), relative spectral rhythm power (RSRP), fronto-occipital rhythm gradient (FORG) in the affected hemisphere $(\mathrm{AH})$ and intact hemisphere $(\mathrm{IH})$, interhemispheric rhythm asymmetry values.

Results. On the basis of cluster analysis 2 types of the brain bioelectric activity changes were identified in patients with SSICH. Type I of EEG pattern was registered in $56.5 \%$ patients, it was characterized by ipsilateral increase of RSRP of $\delta$-range with the dominance of $\theta$-range rhythms in slow-wave activity structure in combination with smoothing of zonal differences of a-range rhythms in $\mathrm{AH}$, whereas type II was characterized by bilateral domination of the RSRP $\delta$-range with an accent in $\mathrm{IH}$ in combination with FORG inversion of $\alpha$-range due to elevation of the $\alpha 2$-subrange in the anterior areas of $\mathrm{IH}$. The patients with type II of EEG pattern were characterized by ipsilateral increase of RSRP of $\delta$-range with the dominance of $\theta$-range rhythms in slow-wave activity structure in combination with smoothing of zonal differences of $\alpha$-range rhythms in $\mathrm{AH}$. The patients with type II of EEG pattern were characterized by more severe brain impairment $(\mathrm{ICH}$ score $3(2 ; 4)$ versus $0(0 ; 1), P<0.0001)$. Type II of EEG pattern was revealed in $94.7 \%$ of patients with medium/severe dysfunction of subtentorial structures (FOUR score $\leq 14$ ), type I - in $92.6 \%$ of patients with low dysfunction or without any dysfunction (FOUR score $>14$ ).

Conclusions. Complex analysis of bioelectric activity of the brain in patients with SSICH allows to identify the integral types of EEG pattern, which represent the functional state of cerebral structures and are associated with the clinical and neuroimaging criteria of midline shift severity.

Ключові слова: внутрішньомозковий крововилив, електроенцефалографія, комп'ютерна томографія.

Патологія. - 2018. T. 15, № 3(44). C. $378-385$

\section{Аіагностичне значення інтегральної оцінки ЕЕГ-патерну в пацієнтів у гострому періоді спонтанного супратенторіального внутрішньомозкового крововияиву}

\section{А. А. Кузнєцов}

Мета роботи - визначити діагностичну інформативність інтегральної оцінки електроенцефалографрічного (ЕЕГ) патерну в пацієнтів зі спонтанним супратенторіальним внутрішньомозковим крововиливом (ССВМК) на підставі зіставлення показників біоелектричної активності головного мозку з клініко-нейровізуалізаційними даними.

Матеріали та методи. Здійснили проспективне, когорне дослідження 46 пацієнтів у гострому періоді ССВМК, що включав комплексне клінічне (з використанням Glasgow Coma Scale, Full Outline of UnResponsiveness (FOUR) score, National Institute of Health Stroke Scale, Intracerebral hemorrhage (ICH) score) та нейровізуалізаційне оцінювання тяжкості ураження церебральних структур у дебюті захворювання. Дослідження спонтанної біоелектричної активності головного мозку виконали в перші 24-48 годин від дебюту ССВМК із визначенням абсолютної спектральної потужності ритмів (АСПР), відносної спектральної потужності ритмів (ВСПР), лобно-потиличних градієнтів ритмів (ЛПГР) різних діапазонів ЕЕГ-патерну в ураженій півкулі (УП) та інтактній півкулі (ІП), а також показників міжпівкульової асиметрії ритмів.

Результати. На підставі кластерного аналізу виділили 2 типи змін біоелектричної активності головного мозку в пацієнтів із ССВМК. I тип ЕЕГ-патерну, зареєстрований в 56,5% випадків, представлений переважно іпсилатеральним підвищенням ВСПР $\delta$-діапазону з домінуванням у структурі повільнохвильової активності ритмів $\theta$-діапазону в комбінації зі збереженням зональних відмінностей ритмів а-діапазону в УП, а II тип характеризувався білатеральним домінуванням ВСПР $\delta$-діапазону з акцентом в ІП в комбінації з інверсією ЛПГР а-діапазону шляхом елевації АСПР а2-піддіапазону в передніх відділах IП. Пацієнти з ІІ типом ЕЕГ-патерну відрізнялися тяжчим пошкодженням церебральних структур (ICH score 3 (2; 4) проти 0 (0; 1), p < 0,0001). У 94,7 \% пацієнтів із клінічними ознаками середньої тяжкості дисфункції субтенторіальних структур (FOUR score $\leq 14)$ виявили II тип ЕEГ-патерну, у 92,6 \% пацієнтів із клінічними ознаками легкої дисфункції або без такої (FOUR score >14) - I тип.

Висновки. Комплексний аналіз показників біоелектричної активності головного мозку в пацієнтів зі ССВМК дає змогу ідентиффікувати інтегральні типи ЕЕГ-патерну, які показують функціональний стан церебральних структур та асоційовані з вираженістю дислокаційного синдрому. 


\section{Аиагностическое значение интеграмьной оценки ЭЭГ-паттерна у пациентов в остром периоде спонтанного супратенториального внутримозгового кровоизлияния}

\section{А. А. Кузнецов}

Цель работы - установить диагностическую информативность интегральной оценки электроэнцефралографического (ЭЭГ) паттерна у пациентов со спонтанным супратенториальным внутримозговым кровоизлиянием (ССВМК) на основании сопоставления показателей биоэлектрической активности головного мозга с клинико-нейровизуализационными данными.

Материалы и методы. Проведено проспективное, когортное исследование 46 пациентов в остром периоде ССВМК, которое включало комплексную клиническую (с использованием Glasgow Coma Scale, Full Outline of UnResponsiveness (FOUR) score, National Institute of Health Stroke Scale, Intracerebral hemorrhage (ICH) score) и нейровизуализационную оценку тяжести повреждения церебральных структур в дебюте заболевания. Исследование спонтанной биоэлектрической активности головного мозга проведено в первые 24-48 часов от дебюта ССВМК с определением абсолютной спектральной мощности ритмов (АСМР), относительной спектральной мощности ритмов (ОСМР), лобно-затылочных градиентов ритмов (ЛЗГР) различных диапазонов ЭЭГ-паттерна в пораженном полушарии (ПП) и интактном полушарии (ИП), а также показателей межполушарной асимметрии ритмов.

Результаты. На основании кластерного анализа выделили 2 типа изменений биоэлектрической активности головного мозга у пациентов с ССВМК. I тип ЭЭГ-паттерна, зарегистрированный в 56,5 \% случаев, представлен преимущественно ипсилатеральным увеличением ОСМР б-диапазона с доминированием в структуре медленноволновой активности ритмов $\theta$-диапазона в сочетании с сохранением зональных различий ритмов а-диапазона в ПП, а II тип характеризовался билатеральным доминированием ОСМР б-диапазона с акцентом в ИП в сочетании с инверсией ЛЗГР а-диапазона за счет элевации ACMP a2-поддиапазона в передних отделах ИП. Пациенты со II типом ЭЭГ-паттерна отличались более тяжелым повреждением церебральных структур (ICH score $3(2 ; 4)$ против $0(0 ; 1), p<0,0001)$. У 94,7 \% пациентов с клиническими признаками умеренной/тяжелой диссрункции субтенториальных структур (FOUR score $\leq 14)$ установлен II тип ЭЭГ-паттерна, у 92,6 \% пациентов с клиническими признаками легкой дисфункции или без таковой (FOUR score >14) - I тип.

Выводы. Комплексный анализ показателей биоэлектрической активности головного мозга у пациентов со ССВМК позволяет идентифицировать интегральные типы ЭЭГ-паттерна, которые отражают функциональное состояние церебральных структур и ассоциированы с выраженностью дислокационного синдрома.

Despite significant progress of fundamental sciences and clinical neurology, acute cerebrovascular pathology is still one of the most difficult and, unfortunately, unresolved problems of modern medicine. The most destructive form of cerebrovascular diseases is cerebral hemorrhagic stroke, which is the leading cause of death and disability of the adult population in most countries of the world [8,11].

One of the most effective ways to increase the effectiveness of therapeutic measures in patients with supratentorial spontaneous intracerebral hemorrhages (SSICH) is the differentiated choice of optimal treatment tactics, taking into consideration the individual prognosis of the acute period outcome of the disease [15]. The aforesaid justifies the relevance of the research which is aimed at the identification of parameters associated with the lethal outcome risk.

Numerous studies have confirmed a high diagnostic and prognostic value of spectral analysis parameters of the bioelectric activity of the brain in case of acute brain injuries which predominantly have ischemic and traumatic genesis $[9,16]$. The expediency of the detection of these indicators in clinical practice as neurophysiological criteria for the assessment of patients' state severity and markers of the effectiveness of the therapy was justified $[1,5,13,14,20]$. At the same time, very few papers were devoted to the study of these aspects in patients with SSICH [6,12].

Moreover, the overwhelming majority of scientific research related to the study of the functional state of cerebral structures within brain injuries of various origins with the use of spectral analysis of bioelectric activity of the brain was aimed at the determination of isolated parameters that are associated with clinical and neuroimaging data and the outcome of the disease $[4,7,10,17]$. Besides, it is necessary to mention that this monoparametric approach has restrictions, since the functional state of the brain in patients with brain damage in supratentorial localization is a very complex and extremely variable set of relied changes of absolute power, structure, zonal distribution of rhythms of different ranges in affected and intact hemispheres, as well as interhemispheric rhythm asymmetry [2]. The aforementioned justifies the expediency of the identification of integral electroencephalographic patterns as they take into consideration a complete set of spectral analysis parameters of bioelectric activity of the brain.

\section{The aim}

Therefore the aim of this study was to verify the diagnostic informative value of the integral evaluation of the electroencephalographic pattern in patients with spontaneous supratentorial intracerebral hemorrhage on the basis of the comparison of brain activity changes with clinical and neuroimaging data.

\section{Materials and methods}

In order to achieve this goal a prospective, cohort study was conducted in 46 patients (27 men and 19 women,
Ключевые слова: внутримозговое кровоизлияние, эмектроэнцефалография, компьютерная томография.

Патология. - 2018. T. 15, № 3(44). -

C. $378-385$ 
median age $67(61-75)$ years) in the acute period of spontaneous hemorrhage in the left (58.7\%) and the right brain hemispheres (41.3\%). The study included patients with SSICH confirmed by clinical and neuroimaging examination who were hospitalized within the first 24 hours from the onset of the disease. The following are criteria for the exclusion from the study:

1) anamnestic data about presence of acute brain circulation disorders, traumatic brain injuries, epileptic seizures;

2) more than 2 lesions;

3) subtentorial lesion localization;

4) decompensated somatic pathology;

5) oncological pathology.

Neuroimaging study was conducted upon admission to hospital, which was performed with the use of a computed tomography scanner "Siemens Somatom Spirit" (Germany). The intracerebral hemorrhage volume (ICHV) was determined with the help of the ellipsoid formula: ICHV $(\mathrm{ml})=(a \cdot b \cdot c) / 2$, where $a, b, c$ are linear lesion sizes $(\mathrm{cm})$. The degree of septum pellucidum displacement and the pineal gland displacement were considered as neuroimaging criteria for the severity of midline shift.

Clinical and neurological examination included the assessment of subtentorial structures dysfunction in accordance with the Glasgow Coma Scale (GCS) score and Full Outline of UnResponsiveness (FOUR) score. The National Institute of Health Stroke Scale (NIHSS) was used in order to determine the level of neurological deficit. Integral neurological and neuroimaging assessment of SSICH severity was performed in accordance with the $\mathrm{ICH}$ scale.

During the first 24-48 hours after SSICH onset all patients underwent electroencephalographic examination held with the use of 21-channel computer electroencephalograph (EEG) "NeuroCom Standard" (XAI-Medica, Ukraine). Electrodes were applied on the basis of the international system "10-20". Artifact removal was carried out using the Independent Component Analysis decomposition procedure (Blind Sourse Separation technology). Spectral analysis of spontaneous bioelectrical activity of the brain was carried out to get the artifact-free epoch using the fast Fourier transform method, while values of average absolute spectral rhythm power (AASRP) were defined separately for the affected hemisphere $(\mathrm{AH})$ and intact hemisphere $(\mathrm{IH})$, and separately for the frontal region (FR) and occipital region (OR) of $\mathrm{AH}$ and $\mathrm{IH}$ : $\delta-(0.5-4.0$ $\mathrm{Hz}), \theta-(4-8 \mathrm{~Hz}), \alpha-(8-13 \mathrm{~Hz}), \beta-(13-35 \mathrm{~Hz})$ ranges, $\theta 1-(4-6 \mathrm{~Hz}), \theta 2-(6-8 \mathrm{~Hz}), \alpha 1-(8-10 \mathrm{~Hz}), \alpha 2-(10-13$ $\mathrm{Hz}), \beta 1-(13-25 \mathrm{~Hz})$ and $\beta 2-(25-35 \mathrm{~Hz})$ subranges $\left(\mu \mathrm{V}^{2}\right)$. Relative spectral rhythm power (RSRP) values within the specified ranges (\%) and integral coefficients, which demonstrate the AASRP of various ranges and subranges ratio of the EEG pattern were also calculated: DTABR $=(\delta+\theta) /(\theta+\beta)$, DTR $=\delta / \theta$, T1T2R $=\theta 1 / \theta 2$, $\mathrm{DAR}=\delta / \alpha, \mathrm{TAR}=\theta / \alpha, \mathrm{ABR}=\alpha / \beta, \mathrm{A} 1 \mathrm{~A} 2 \mathrm{R}=\alpha 1 / \alpha 2$, $B 1 B 2 R=\beta 1 / \beta 2$. The values of fronto-occipital rhythm gradient (FORG) were used for a quantitative assessment of zonal differences in the distribution of rhythms in $\mathrm{AH}$ and $\mathrm{IH}$, which were calculated with the following formula: $F O R G=(A A S R P$ in FR - AASRP in OR $) /($ AASRP in FR + AASRP in OR). The severity of interhemispheric rhythm asymmetry (IHRA) was determined in accordance with the following formula: IHRA = (AASRP in $\mathrm{AH}-\mathrm{AASRP}$ in $\mathrm{IH}$ ) / (AASRP in AH + AASRP in $\mathrm{H}$ ).

Statistical analysis of the results was held with the help of Statistica 13.0 software (StatSoft Inc., USA, series number JPZ804I382130ARCN10-J) and MedCalc (version 16.4). Since most of the studied parameters according to the Shapiro-Wilk criterion had a distribution that differed from the normal, descriptive statistics are presented in the form of a median and interquartile range. The integral types of EEG pattern were determined on the basis of a cluster analysis. Within this analysis agglomerative-hierarchical algorithms (construction of vertical dendrograms using the Ward method) and iterative algorithms (k-means method in McKean's variation) were used. In order to determine the intergroup differences of the studied traits, the Mann-Whitney test was used. The relations between qualitative (discrete) signs were assessed on the basis of the analysis of contingency tables using Pearson's chi-squared test. The values $\mathrm{P}<0.05$ were considered as statistically significant results.

\section{Results}

Upon admission to hospital focal neurological deficit of various severity was registered in all patients, while the NIHSS score value in the studied cohort was 14 (7; 21). Clinical signs of dislocation syndrome in the onset of SSICH were revealed in $23(50.0 \%)$ patients. In the clinical structure of subtentorial structures dysfunction in this subcohort of patients variable combinations of consciousness reduction (100.0\%) with heterogeneous ophthalmoplegic syndrome ( $91.3 \%)$, brain stem reflexes disorders (65.2\%), muscular dystonic syndrome (56.5\%) and respiratory pattern disorders (47.8\%), while the dysfunction severity of subtentorial structures corresponded to the following gradation: low (FOUR score 15) in $17.4 \%$ of cases, medium (FOUR score 13-14) - to $26.1 \%$, severe (FOUR score $\leq 12$ ) $-50.0 \%$. The FOUR score value in the general cohort constituted $15(11 ; 16)$, GCS score $-14(8 ; 15)$.

In accordance with the neuroimaging study, lateral displacement of median brain structures was revealed in $34(73.9 \%)$ patients. The values of the septum pellucidum displacement and pineal gland displacement constituted 3 $(1 ; 5) \mathrm{mm}$ (for both indexes), ICHV - $13.8(5.2 ; 65.0) \mathrm{ml}$.

The selection of integral types of electroencephalographic pattern in the studied patients was made at 2 stages. At the first stage, the hierarchical-agglomeration algorithm of cluster analysis was used in order to classify observations, whereas the results of spectral analysis of spontaneous bioelectrical affected and unaffected hemispheres (AASRP, RSRP, FORG, IHAR) used as signs for classification. Since the Euclidean metric was used to estimate the intercluster distance, the studied parameters were previously normalized. The Ward method was used in order to merge observations into clusters.

The analysis of the vertical dendrogram suggests that electroencephalographic patterns in studied patients with SSICH were divided into 2 groups (Fig. 1). 


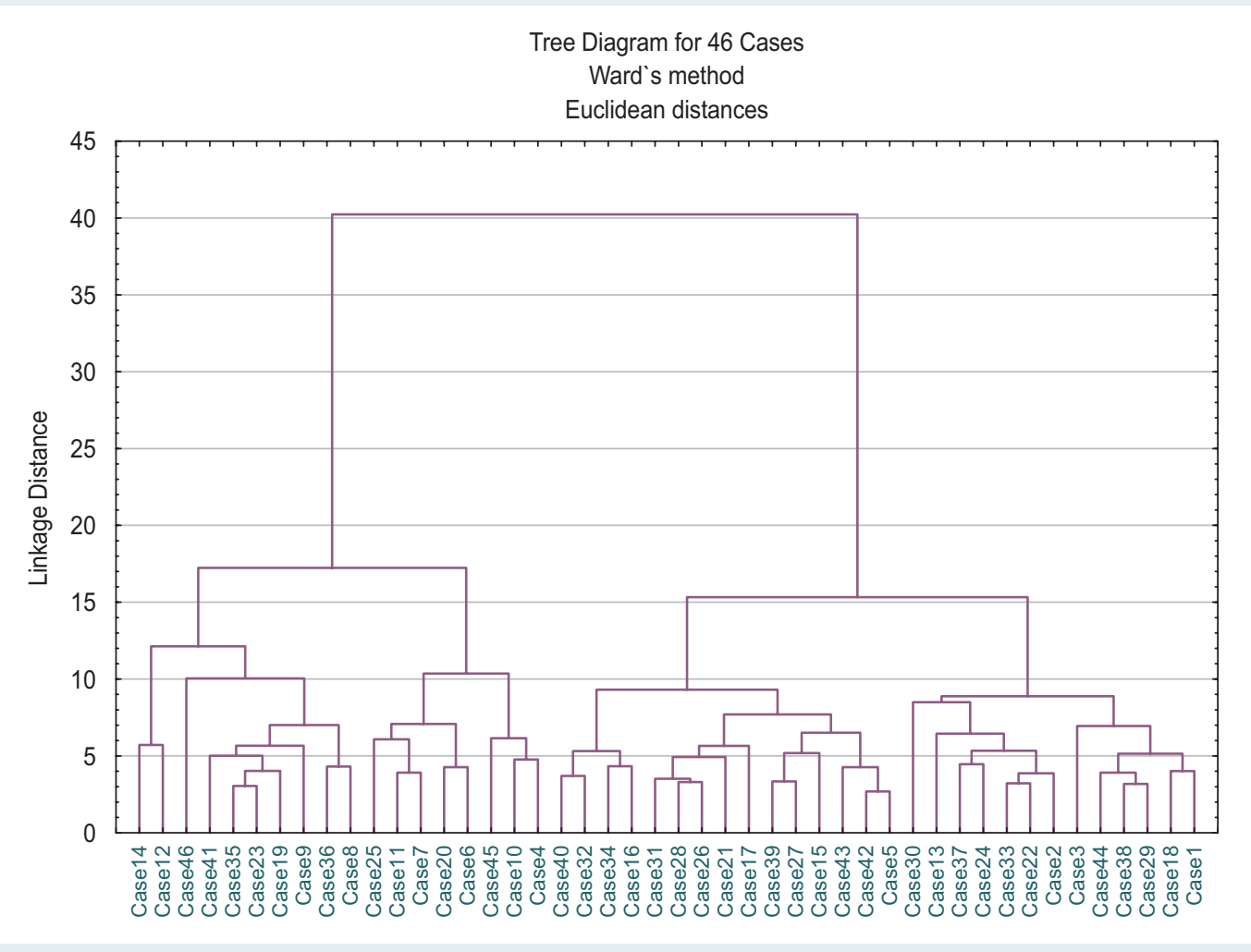

Fig. 1. The results of hierarchical clustering of observations on the basis of a set of parameters of the spectral analysis of spontaneous bioelectrical activity of the brain (vertical dendrogram with the assessment of intercluster distance in the Euclidean metric, Ward method).

At the second stage, two types of EEG pattern were selected using iterative cluster analysis algorithm (k-means method in McKean's variation).

Depending on the type of EEG pattern, patients were divided into 2 groups - $26(56.5 \%)$ and 20 (43.5\%) patients, respectively. Comparative analysis of RSRP of $\mathrm{OH}$ and $\mathrm{IH}$ in patients with different types of EEG pattern is presented in Table 1.

It was determined that patients of the second group had more severe violations of the bioelectrical activity of the affected and intact hemispheres. Type II of the EEG pattern was characterized by bilateral dominance (with an accent in $\mathrm{IH}$ ) of slow-wave activity, predominantly of the $\delta$-range, combined with depression of $\alpha$ - and $\beta$-ranges. RSRP values of $\delta$-range constituted 57.7 (46.0; 70.9) \% in $\mathrm{AH}$ and $60.8(49.1 ; 70.8) \%$ in $\mathrm{IH}$, which exceeded by 3.2 and 4.1 times respectively the values of these indexes in patients with type I of the EEG pattern ( $P<0.0001$ for both parameters). No statistically significant intergroup differences in the RSRP $\theta$-range of the $\mathrm{AH}$ and $\mathrm{IH}$ were found. The elevation of the RSRP $\theta 1$-subrange characterized type II of EEG pattern (16.5 (12.6; 24.1$) \%$ versus $10.8(8.5 ; 13.9) \%, P=0.0125)$, while the RSRP values of $\alpha$ - and $\beta$-ranges were respectively $6.9(P<0.0001)$ and $3.7(P<0.0001)$ times lower in the $\mathrm{AH}$, in $6.7(\mathrm{P}<0.0001)$ and $3.1(\mathrm{P}<0.0001)$ times lower in the IH. Type I of the EEG pattern was characterized by more pronounced disorder of bioelectric activity in the affected hemisphere (RSRP level of $\delta$-range in $\mathrm{AH}$ was $18.1(10.9 ; 30.1) \%$ versus $14.7(9.0 ; 20.3) \%$ in $\mathrm{IH}$;
RSRP level of $\alpha$-range constituted respectively 27.7 (19.1; $41.7) \%$ and against $35.7(26.3 ; 44.5) \%)$.

On the basis of a comparative analysis of the values of integral coefficients, the structure of changes in bioelectrical activity of the brain in the studied subcohorts of patients was detalized (Table 2).

It was determined that bilateral elevation of slow-wave activity in patients with type II of EEG pattern dominated in IH (DTABR value constituted $9.5(6.0 ; 13.6)$ in IH versus $7.9(4.6 ; 17.2)$ in $A H)$. The center of gravity shift of the slow-wave activity to $\delta$-range area was also distinctive (the DTR value constituted 2.3 $(1.3 ; 4.7)$ and $2.6(1.7 ; 3.5)$ in the $\mathrm{AH}$ and $\mathrm{IH}$ respectively), whereas type I was characterized by the center of gravity shift of the slow-wave activity to $\theta$-range area (the DTR value constituted $0.6(0.5$; $1.0)$ and 0.5 (0.3; 0.9$)$ in $A H$ and $\mathrm{IH}$ respectively). Type II of EEG pattern was characterized by the dominance of $\theta 1$-subband oscillations in $\theta$-range rhythms structure (T1T2R value constituted $1.8(1.5 ; 2.7)$ and $2.5(1.9 ; 3.8)$ in $\mathrm{AH}$ and $\mathrm{IH}$ respectively). $\theta 2$-subranges dominated in type I of EEG pattern (T1T2R value constituted $0.7(0.5 ; 1.1)$ and $0.7(0.4 ; 1.0)$ in $\mathrm{AH}$ and $\mathrm{IH}$ respectively). In the group of patients with type II of EEG pattern, DAR and TAR levels in $\mathrm{AH}$ and $\mathrm{IH}$ were significantly higher, while the $\mathrm{ABR}$ and $A 1 A 2 R$ levels in $\mathrm{IH}$ were lower than in patients with type I of EEG pattern. Thus, more pronounced disorders of bioelectrical activity of the brain in patients with type I of EEG pattern were registered in the $\mathrm{AH}$, and in the $\mathrm{IH}$ - in patients with type II. The latter was also confirmed by intergroup differences between IHRA values of the $\delta$-range 
Table 1. Comparative analysis of RSRP (\%) of $\mathrm{OH}$ and $\mathrm{IH}$ in patients with different types of EEG pattern.

\begin{tabular}{|c|c|c|c|}
\hline Indexes & $\begin{array}{l}\text { I type of EEG pattern } \\
(\mathrm{n}=26)\end{array}$ & $\begin{array}{l}\text { Il type of EEG pattern } \\
(n=20)\end{array}$ & $\mathbf{P}$ \\
\hline RSRP $\delta A H$ & $18.1(10.9 ; 30.1)$ & $57.7(46.0 ; 70.9)$ & $<0.0001$ \\
\hline RSRP $\theta 1 \mathrm{AH}$ & $11.3(7.4 ; 15.8)$ & $15.0(9.6 ; 22.1)$ & 0.2757 \\
\hline RSRP $\theta 2 \mathrm{AH}$ & $13.9(10.9 ; 23.1)$ & $6.4(4.5 ; 11.0)$ & 0.0013 \\
\hline RSRP $\theta A H$ & $27.7(21.8 ; 39.7)$ & $24.7(14.9 ; 37.5)$ & 0.3973 \\
\hline RSRP a1 AH & $18.7(10.6 ; 25.2)$ & $3.2(1.7 ; 7.2)$ & $<0.0001$ \\
\hline RSRP $\propto 2 \mathrm{AH}$ & $11.2(5.5 ; 15.7)$ & $2.0(1.3 ; 3.6)$ & $<0.0001$ \\
\hline RSRP $\propto$ AH & $27.7(19.1 ; 41.7)$ & $4.8(3.4 ; 11.5)$ & $<0.0001$ \\
\hline RSRP $\beta 1 \mathrm{AH}$ & $14.3(9.1 ; 19.3)$ & $3.8(1.9 ; 7.8)$ & $<0.0001$ \\
\hline RSRP $\beta 2 \mathrm{AH}$ & $1.5(1.2 ; 2.9)$ & $0.9(0.2 ; 1.9)$ & 0.0142 \\
\hline RSRP $\beta A H$ & $15.7(10.9 ; 25.4)$ & $4.3(2.7 ; 9.6)$ & $<0.0001$ \\
\hline RSRP $\delta I H$ & $14.7(9.0 ; 20.3)$ & $60.8(49.1 ; 70.8)$ & $<0.0001$ \\
\hline RSRP $\theta 1 \mathrm{IH}$ & $10.8(8.5 ; 13.9)$ & $16.5(12.6 ; 24.1)$ & 0.0125 \\
\hline RSRP $\theta 2 \mathrm{IH}$ & $14.6(12.1 ; 22.9)$ & $4.9(4.0 ; 9.5)$ & $<0.0001$ \\
\hline RSRP $\theta$ IH & $28.9(20.8 ; 37.6)$ & $24.0(17.1 ; 32.9)$ & 0.1819 \\
\hline RSRP a1 IH & $26.0(16.7 ; 31.9)$ & $3.1(1.7 ; 5.0)$ & $<0.0001$ \\
\hline RSRP $\propto 2$ IH & $8.3(5.7 ; 16.2)$ & $2.0(1.5 ; 3.1)$ & $<0.0001$ \\
\hline RSRP a IH & $35.7(26.3 ; 44.5)$ & $5.3(3.4 ; 8.0)$ & $<0.0001$ \\
\hline RSRP $\beta 11 \mathrm{IH}$ & $12.2(9.9 ; 17.3)$ & $3.1(1.8 ; 5.6)$ & $<0.0001$ \\
\hline RSRP $\beta 2 \mathrm{IH}$ & $1.5(1.0 ; 2.6)$ & $0.5(0.2 ; 1.7)$ & 0.0067 \\
\hline RSRP $\beta \| H$ & $14.1(11.0 ; 19.4)$ & $4.5(2.0 ; 7.5)$ & $<0.0001$ \\
\hline
\end{tabular}

Table 2. Comparative analysis of integral coefficients in $\mathrm{AH}$ and $\mathrm{IH}$ in patients with different types of EEG pattern

\begin{tabular}{l|l|l|l|} 
Parameters & $\begin{array}{l}\text { I type of EEG pattern } \\
(\mathbf{n}=\mathbf{2 6})\end{array}$ & $\begin{array}{l}\text { II type of EEG pattern } \\
(\mathbf{n}=\mathbf{2 0})\end{array}$ & $\mathbf{P}$ \\
\hline DTABR AH & $1.0(0.5 ; 1.7)$ & $7.9(4.6 ; 17.2)$ & $<0.0001$ \\
\hline DTR AH & $0.6(0.5 ; 1.0)$ & $2.3(1.3 ; 4.7)$ & $<0.0001$ \\
\hline T1T2R AH & $0.7(0.5 ; 1.1)$ & $1.8(1.5 ; 2.7)$ & 0.0002 \\
\hline DAR AH & $0.7(0.3 ; 1.3)$ & $11.5(4.6 ; 19.8)$ & $<0.0001$ \\
\hline TAR AH & $1.0(0.5 ; 1.9)$ & $4.1(2.0 ; 5.7)$ & $<0.0001$ \\
\hline ABR AH & $2.0(1.3 ; 2.8)$ & $1.4(0.8 ; 2.0)$ & 0.1893 \\
\hline A1A2R AH & $1.7(1.2 ; 2.7)$ & $1.8(1.2 ; 2.6)$ & 0.9563 \\
\hline B1B2R AH & $8.4(4.8 ; 10.0)$ & $6.1(3.3 ; 7.2)$ & 0.0819 \\
\hline DTABR IH & $0.9(0.6 ; 1.3)$ & $9.5(6.0 ; 13.6)$ & $<0.0001$ \\
\hline DTR IH & $0.5(0.3 ; 0.9)$ & $2.6(1.7 ; 3.5)$ & $<0.0001$ \\
\hline T1T2R IH & $0.7(0.4 ; 1.0)$ & $2.5(1.9 ; 3.8)$ & $<0.0001$ \\
\hline DAR IH & $0.5(0.2 ; 0.7)$ & $11.6(6.4 ; 19.9)$ & $<0.0001$ \\
\hline TAR IH & $0.8(0.5 ; 1.1)$ & $5.0(2.5 ; 6.9)$ & $<0.0001$ \\
\hline ABR IH & $2.7(1.7 ; 3.7)$ & $1.6(0.9 ; 2.3)$ & 0.0067 \\
\hline A1A2R IH & $2.6(1.5 ; 4.1)$ & $1.5(1.1 ; 2.3)$ & 0.0172 \\
\hline B1B2R IH & $8.4(4.8 ; 10.0)$ & $6.1(3.3 ; 7.2)$ & 0.0819 \\
\hline & & & \\
\hline
\end{tabular}

Table 3. Comparative analysis of IHRA values in patients with different types of EEG pattern

\begin{tabular}{l|l|l|l|} 
Parameters & $\begin{array}{l}\text { I type of EEG pattern } \\
(\mathbf{n}=\mathbf{2 6})\end{array}$ & $\begin{array}{l}\text { II type of EEG pattern } \\
(\mathbf{n}=\mathbf{2 0})\end{array}$ & $\mathbf{P}$ \\
\hline IHRA $\delta$ & $0.074(-0.015 ; 0.178)$ & $-0.120(-0.275 ; 0.088)$ & 0.0095 \\
\hline IHRA $\theta 1$ & $-0.049(-0.228 ; 0.248)$ & $-0.129(-0.398 ; 0.068)$ & 0.0707 \\
\hline IHRA $\theta 2$ & $-0.041(-0.229 ; 0.215)$ & $-0.105(-0.232 ; 0.076)$ & 0.4616 \\
\hline IHRA $\theta$ & $-0.044(-0.133 ; 0.103)$ & $-0.144(-0.316 ; 0.031)$ & 0.1819 \\
\hline IHRA $\alpha 1$ & $-0.145(-0.385 ;-0.012)$ & $-0.179(-0.429 ; 0.146)$ & 0.8693 \\
\hline IHRA $\alpha 2$ & $-0.023(-0.200 ; 0.181)$ & $-0.141(-0.282 ;-0.030)$ & 0.2048 \\
\hline IHRA $\alpha$ & $-0.139(-0.310 ;-0.043)$ & $-0.116(-0.375 ; 0.051)$ & 0.9040 \\
\hline IHRA $\beta 1$ & $-0.006(-0.154 ; 0.043)$ & $-0.095(-0.258 ; 0.044)$ & 0.4616 \\
\hline IHRA $\beta 2$ & $-0.001(-0.066 ; 0.140)$ & $0.056(-0.117 ; 0.176)$ & 0.9040 \\
\hline IHRA $\beta$ & $0.010(-0.145 ; 0.057)$ & $-0.082(-0.226 ; 0.055)$ & 0.5170 \\
\hline IHRA total & $-0.059(-0.188 ; 0.073)$ & $-0.060(-0.151 ; 0.040)$ & 0.9738 \\
\hline
\end{tabular}

$(0.074(-0.015 ; 0.178)$ versus $-0.120(-0.275 ; 0.088)$, $\mathrm{P}=0.0095)$ (Table 3).

It was determined that type II of EEG pattern was characterized by more pronounced disorders of zonal differences of $\alpha$-range rhythms $(0.069(-0.084 ; 0.306)$ versus $-0.122(-0.304 ; 0.041)$ in $\mathrm{AH}, \mathrm{P}=0.0125 ; 0.103(-0.108$; $0.195)$ versus $-0.198(-0.359 ; 0.004)$ in $\mathrm{IH}, \mathrm{P}=0.0008)$ due to a2-subrange $(0.106(-0.125 ; 0.276)$ versus -0.104 $(-0.297 ; 0.061)$ in $\mathrm{AH}, \mathrm{P}=0.0395 ; 0.027(-0.109 ; 0.306)$ versus $-0.157(-0.442 ; 0.018), P=0.0017)$ (Table 4).

The obtained data certify the elevation of AASRP of a2-subrange in frontal areas of $\mathrm{IH}$ in patients with type II of EEG pattern, which was confirmed by corresponding IHRA values $(-0.147$ (-0.403; 0.069) versus $0.073(-0.072$; $0.217), P=0.0395$ ) (Table 5).

In the group of patients with type I of EEG pattern the dysfunction of subtentorial structures was not revealed in $88.5 \%$ of cases, low dysfunction (FOUR score 15) was verified in $7.7 \%$, medium (FOUR score 13-14) - only in $3.8 \%$, whereas in patients with type II severe dysfunction of subtentorial structures (FOUR score $\leq 12$ ) dominated $(65.0 \%)$, medium dysfunction was verified in $25.0 \%$ of patients, low dysfunction - only in $10.0 \%$. On the basis of the analysis of frequency distribution of grades assessment of FOUR score in patients with different types of EEG patterns it was determined that the integral type of EEG pattern was associated with functional state of subtentorial structures (Chi-squared $=38.5, \mathrm{P}<0.0001$ ), whereas type II of EEG pattern was revealed in $94.7 \%$ of patients with medium/severe dysfunction of subtentorial structures, type I - in $92.6 \%$ of patients with low dysfunction or without any dysfunction. Thus, pattern type II of bioelectrical activity of the brain is the integral electroencephalographic diagnostic criterion of medium/ severe dysfunction of subtentorial structures in patients with SSICH (sensivity = 94.7\%, specificity $=92.6 \%$ ). On the basis of comparative analysis of clinical data it was determined that patients with type II of EEG pattern had statistically higher values of NIHSS score $(21(15 ; 30)$ versus $7(5 ; 11), P<0.0001)$ in combination with lower values of GCS score $(8(4 ; 11)$ versus $15(14 ; 15)$, $\mathrm{P}<0.0001)$ and FOUR score $(12(5 ; 15)$ versus $16(16 ; 16)$, $P<0.0001)$.

In $50.0 \%$ patients with type I of EEG pattern the midline shift was not detected. Septum pellucidum displacement 1-3 mm was registered in $38.5 \%$ cases, $4-5 \mathrm{~mm}$ and $>5 \mathrm{~mm}$ - in $11.5 \%$ (in equal shares), whereas midline shift was diagnosed in all the patients with type II of EEG pattern. Septum pellucidum displacement 4-5 $\mathrm{mm}$ and $>5 \mathrm{~mm}$ was registered in $80.0 \%$ cases (in equal shares), 1-3 $\mathrm{mm}$ - in $20.0 \%$. On the basis of the analysis of frequency distribution of grades assessment of septum pellucidum displacement in patients with different types of EEG patterns it was determined that the integral type of EEG pattern was associated with midline shift severity (Chisquared $=21.4, \mathrm{P}=0.0001)$. The patients with type II of EEG pattern had statistically higher values of ICHV (67.9 (24.0; 98.1) $\mathrm{mL}$ versus 5.3 (2.8-8.9) $\mathrm{mL}, \mathrm{P}<0.0001)$, septum pellucidum displacement $(5(4 ; 9) \mathrm{mm}$ versus $1(0 ; 3) \mathrm{mm}, \mathrm{P}<0.0001)$, pineal gland displacement $(5(4 ; 7) \mathrm{mm}$ versus $1(0 ; 3) \mathrm{mm}, \mathrm{P}<0.0001)$ and $\mathrm{ICH}$ score (3 $(2 ; 4)$ versus $0(0 ; 1), P<0.0001)$. 


\section{Discussion}

Thus, the step-by-step use of hierarchical, agglomerative and iterative algorithms for cluster analysis along with the further detection of intergroup differences allowed to identify 2 types of electroencephalographic pattern in patients with $\mathrm{SSICH}$ and to verify their diagnostic criteria. Thus, type I of EEG pattern was characterized by the predominance of violations in the AH. In the structure of slow-wave activity, $\theta$-range rhythms dominated in the AH (DTR median constituted 0.6). The values of IHRA median of the $\delta$-range $(0.074)$ indicated the predominance of ipsilateral nature of slow-wave elevation in this group of patients. Zonal differences remained in the rhythms of a-range in the $\mathrm{AH}$, which was confirmed by the corresponding values of FORG $(-0.122(-0.304$; $0.041)$ for the $\alpha-b a n d$ and $-0.104(-0.297 ; 0.061)$ for the $\alpha 2$ subband). The results of the analysis of clinical neuroimaging data in this subcohort of patients serve as a basis to consider type I of EEG pattern as an integral neurophysiological marker of ipsilateral focal lesion of specific systems of supratentorial localization in combination with low dysfunction of synchronizing systems of diencephalic level due to slightly pronounced displacement of median brain structures.

Type II of EEG pattern was characterized by more pronounced dysfunction of the bioelectric activity of $\mathrm{AH}$ and $\mathrm{IH}$. Bilateral elevation of slow-wave activity was distinctive. $\delta$-range rhythms dominated in its structure, which was confirmed by corresponding RSRP levels of the $\delta$-range (57.7 (46.0; 70.9) \% in AH, 60.8 (49.1; $70.8) \%$ in IH), RSRP of $\alpha$-range $(4.8(3.4 ; 11.5) \%$ in $\mathrm{AH}, 5.3(3.4 ; 8.0) \%$ in IH), DTABR $(7.9(4.6 ; 17.2)$ in $\mathrm{AH}, 9.5(6.0 ; 13.6)$ in IH), DTR $(2.3(1.3 ; 4.7)$ in $\mathrm{AH}, 2.6$ $(1.7 ; 3.5)$ in IH), DAR (11.5 (4.6; 19.8) in AH, 11.6 (6.4; 19.9) in IH), TAR $(4.1(2.0 ; 5.7)$ in AH, $5.0(2.5 ; 6.9)$ in $\mathrm{IH})$. We should note the predominance of slow-wave activity elevation in the $\mathrm{IH}$, which was indicated by the value of IHRA median of $\delta$-range $(-0.118(-0.308$; 0.071 ) versus $0.117(-0.006 ; 0.261), P=0.0018)$. The results of the analysis of clinical and neuroimaging criteria for the assessment of the severity of damage and dysfunction of cerebral structures in the studied subcohort of patients (FOUR score constituted $8(3 ; 13)$, septum pellucidum displacement $-5(4 ; 9)$, pineal gland displacement - $5(4 ; 9))$ allow to represent the complex of these changes in the bioelectrical activity of the brain as an integral electroencephalographic marker of deep depression of synchronizing systems of the diencephalic level with the development of functional interhemispheric diaschisis as a result of the severe dislocation of subtentorial structures. The obtained data are consistent with the results of other studies. Thus, in the study of M. Purandare et al. (2018) it was determined that RSRP levels of $\delta$-, $\alpha$-ranges, DTABR, DAR in patients with SSICH were associated with Glasgow coma scale score and ICHV [12]. In the study by P. Xu et al. (2008) it was revealed that intracranial hypertension and the development of dislocation syndrome in patients with intracerebral hemorrhage are accompanied by the elevation of the absolute spectral power of slow-wave activity with an accented range within $0.5-3.0 \mathrm{~Hz}$ [18]. The study by G. Assenza et al. (2013) demonstrated the diagnostic
Table 4. Comparative analysis of fronto-occipital rhythm gradients in $\mathrm{AH}$ and $\mathrm{IH}$ in patients with different types of EEG pattern

\begin{tabular}{l|l|l|l}
\hline Parameters & $\begin{array}{l}\text { I type of EEG pattern } \\
(\mathbf{n}=\mathbf{2 6})\end{array}$ & $\begin{array}{l}\text { II type of EEG pattern } \\
(\mathbf{n}=\mathbf{2 0})\end{array}$ & $\mathbf{P}$ \\
\hline FORG $\delta$ AH & $0.272(0.047 ; 0.386)$ & $0.150(-0.002 ; 0.266)$ & 0.1893 \\
\hline FORG $\theta 1$ AH & $0.143(-0.092 ; 0.335)$ & $0.316(0.014 ; 0.438)$ & 0.1543 \\
\hline FORG $\theta 2$ AH & $0.146(-0.102 ; 0.322)$ & $0.015(-0.207 ; 0.247)$ & 0.6847 \\
\hline FORG $\theta$ AH & $0.087(-0.076 ; 0.244)$ & $0.223(0.074 ; 0.416)$ & 0.1893 \\
\hline FORG $\alpha 1$ AH & $-0.097(-0.317 ; 0.123)$ & $0.204(-0.144 ; 0.319)$ & 0.0607 \\
\hline FORG $\alpha 2$ AH & $-0.104(-0.297 ; 0.061)$ & $0.106(-0.125 ; 0.276)$ & 0.0395 \\
\hline FORG $\alpha$ AH & $-0.122(-0.304 ; 0.041)$ & $0.069(-0.084 ; 0.306)$ & 0.0125 \\
\hline FORG $\beta 1$ AH & $0.051(-0.044 ; 0.134)$ & $0.001(-0.121 ; 0.141)$ & 0.4889 \\
\hline FORG $\beta 2$ AH & $0.087(-0.074 ; 0.343)$ & $-0.046(-0.193 ; 0.094)$ & 0.0946 \\
\hline FORG $\beta$ AH & $0.033(-0.070 ; 0.134)$ & $-0.016(-0.130 ; 0.113)$ & 0.2957 \\
\hline FORG $\delta$ IH & $0.116(-0.116 ; 0.251)$ & $0.086(0.014 ; 0.466)$ & 0.4483 \\
\hline FORG $\theta 1$ IH & $0.145(-0.049 ; 0.307)$ & $0.071(-0.061 ; 0.177)$ & 0.3385 \\
\hline FORG $\theta 2$ IH & $0.070(-0.076 ; 0.270)$ & $-0.161(-0.274 ;-0.023)$ & 0.0281 \\
\hline FORG $\theta$ IH & $0.146(-0.089 ; 0.263)$ & $-0.017(-0.113 ; 0.175)$ & 0.2128 \\
\hline FORG $\alpha 1$ IH & $-0.142(-0.376 ; 0.018)$ & $0.010(-0.191 ; 0.276)$ & 0.0547 \\
\hline FORG $\alpha 2$ IH & $-0.157(-0.442 ; 0.018)$ & $0.027(-0.109 ; 0.306)$ & 0.0017 \\
\hline FORG $\alpha$ IH & $-0.198(-0.359 ; 0.004)$ & $0.103(-0.108 ; 0.195)$ & 0.0008 \\
\hline FORG $\beta 1$ IH & $-0.004(-0.111 ; 0.171)$ & $0.010(-0.208 ; 0.306)$ & 0.9738 \\
\hline FORG $\beta 2$ IH & $0.208(-0.066 ; 0.395)$ & $0.073(-0.071 ; 0.277)$ & 0.5313 \\
\hline FORG $\beta$ IH & $0.043(-0.096 ; 0.182)$ & $0.007(-0.182 ; 0.301)$ & 0.7504 \\
\hline
\end{tabular}

Table 5. Comparative analysis of IHRA values in frontal and caudal areas of brain hemispheres in patients with different types of EEG pattern.

\begin{tabular}{|c|c|c|c|}
\hline Parameters & $\begin{array}{l}\text { I type of EEG pattern } \\
(\mathrm{n}=26)\end{array}$ & $\begin{array}{l}\text { II type of EEG pattern } \\
(n=20)\end{array}$ & $\mathbf{P}$ \\
\hline IHRA $\delta$ FR & $0.117(-0.006 ; 0.261)$ & $-0.118(-0.308 ; 0.071)$ & 0.0018 \\
\hline IHRA $\theta 1 \mathrm{FR}$ & $0.078(-0.128 ; 0.199)$ & $0.100(-0.147 ; 0.210)$ & 0.9040 \\
\hline IHRA $\theta 2$ FR & $-0.051(-0.231 ; 0.087)$ & $0.187(-0.115 ; 0.236)$ & 0.0315 \\
\hline IHRA $\theta$ FR & $-0.051(-0.175 ; 0.110)$ & $0.067(-0.113 ; 0.224)$ & 0.2048 \\
\hline IHRA a1 FR & $-0.145(-0.199 ; 0.055)$ & $-0.050(-0.258 ; 0.176)$ & 0.5906 \\
\hline IHRA \&2 FR & $0.073(-0.072 ; 0.217)$ & $-0.147(-0.403 ; 0.069)$ & 0.0395 \\
\hline IHRA a FR & $-0.055(-0.166 ; 0.067)$ & $-0.148(-0.296 ; 0.058)$ & 0.5459 \\
\hline IHRA $\beta 1$ FR & $0.000(-0.068 ; 0.099)$ & $-0.118(-0.185 ; 0.000)$ & 0.0707 \\
\hline IHRA $\beta 2$ FR & $-0.047(-0.173 ; 0.171)$ & $-0.143(-0.243 ; 0.088)$ & 0.3275 \\
\hline IHRA $\beta$ FR & $-0.003(-0.057 ; 0.096)$ & $-0.084(-0.196 ; 0.015)$ & 0.0466 \\
\hline IHRA total FR & $0.011(-0.049 ; 0.115)$ & $-0.026(-0.194 ; 0.084)$ & 0.2856 \\
\hline IHRA $\delta$ OR & $0.044(-0.191 ; 0.177)$ & $0.008(-0.248 ; 0.150)$ & 0.5906 \\
\hline IHRA $\theta 1$ OR & $-0.049(-0.228 ; 0.248)$ & $-0.129(-0.398 ; 0.068)$ & 0.0707 \\
\hline IHRA $\theta 2$ OR & $-0.041(-0.229 ; 0.215)$ & $-0.105(-0.232 ; 0.076)$ & 0.4616 \\
\hline IHRA $\theta$ OR & $-0.044(-0.133 ; 0.103)$ & $-0.144(-0.316 ; 0.031)$ & 0.1819 \\
\hline IHRA a1 OR & $-0.145(-0.385 ;-0.012)$ & $-0.179(-0.429 ; 0.146)$ & 0.8693 \\
\hline IHRA \&2 OR & $-0.023(-0.200 ; 0.181)$ & $-0.141(-0.282 ;-0.030)$ & 0.2048 \\
\hline IHRA $\propto$ OR & $-0.139(-0.310 ;-0.043)$ & $-0.116(-0.375 ; 0.051)$ & 0.9040 \\
\hline IHRA $\beta 1$ OR & $-0.006(-0.154 ; 0.043)$ & $-0.095(-0.258 ; 0.044)$ & 0.4616 \\
\hline IHRA $\beta 2$ OR & $-0.001(-0.066 ; 0.140)$ & $0.056(-0.117 ; 0.176)$ & 0.9040 \\
\hline IHRA $\beta$ OR & $0.010(-0.145 ; 0.057)$ & $-0.082(-0.226 ; 0.055)$ & 0.5170 \\
\hline IHRA total OR & $-0.059(-0.188 ; 0.073)$ & $-0.060(-0.151 ; 0.040)$ & 0.9738 \\
\hline
\end{tabular}

significance of the contralateral elevation of the absolute spectral rhythm power as a neurophysiological marker of hemispheric diaschisis in patients in the acute period of severe supratentorial stroke [3]. In the study of M. E. Wolf et al. (2017), it was found that generalized (bilateral) changes of the bioelectric activity of the brain reflect the severity of supratentorial structures damage in patients with cerebral ischemic hemispheric stroke, not the focal ones [19]. The numerous studies demonstrate a high diagnostic informative value of the integral EEG 
pattern coefficients, which reflect the severity of slowwave activity within the assessment of the severity of acute brain damage of ischemic and traumatic genesis $[2,4,5,17]$.

The conducted study allowed us to obtain data on reciprocal changes in the anterior and posterior gradient of EEG pattern rhythms in patients with SSICH. Thus, type I of the EEG pattern was characterized by the maintenance of the negative FORG $\alpha$-band in both hemispheres, which indicated the integrity of the interhemispheric organization of corresponding rhythms, whereas type II of the EEG pattern had a bilateral inversion of FORG $\alpha$-band 0.069 $(-0.084 ; 0.306)$ in $\mathrm{AH}, 0.103(-0.108 ; 0.195)$ in the $\mathrm{IH})$ due to a2-subrange $(0.106(-0.125 ; 0.276)$ in the $\mathrm{AH}, 0.027$ $(-0.109 ; 0.306)$ in the $\mathrm{IH})$. The revealed changes in $\mathrm{AH}$ reflected the severity of focal lesions of supratentorial structures, whereas the genesis of contralateral inversion of these indicators was due to the decrease of AASRP of a2-subrange in caudal areas of PI (as a marker of the depression of pacemaker activity of thalamic structures) in combination with the elevation of AASRP a2-subrange in anterior areas of $\mathrm{IH}$ (as a marker of the irritation of non-specific systems of diencephalic level under conditions of pronounced lateral displacement of median brain structures), which was further confirmed by negative values of IHRA $\alpha 2$-subrange in the frontal area $(-0.147$ $(-0.403 ; 0.069)$ versus $0.073(-0.072 ; 0.217), P=0.0395)$. The results of clinical neuroimaging data analysis in the group of patients with type II of EEG pattern make it possible to interpret the indicated changes of FORG a2-subrange in $\mathrm{IH}$ combined with the formation of negative IHRS of $\alpha 2$-subrange in anterior areas of the brain as a neurophysiological criterion for the assessment of the dysfunction severity of the midbrain structures due to their lateral dislocation.

Thus, the study identified EEG pattern types in patients with $\mathrm{SSICH}$, which reflect the main consistency of the reorganization of bioelectric activity of the brain in the acute period of the disease. It was defined that the integral assessment of the bioelectrical activity of the brain with the use of the spectral analysis is characterized by a high sensitivity (over 90\%) to changes of the functional state of cerebral structures in the onset of $\mathrm{SSICH}$, which explains the expediency of the determination of EEG pattern type (in accordance with the developed neurophysiological diagnostic criteria) in order to improve the integrated assessment of damage severity of brain structures in this group of patients. It is also necessary to conduct further prospective studies as for the corresponding statistical power for the verification of the prognostic informative value of the integral assessment of the EEG pattern in patients with $\mathrm{SSICH}$.

\section{Conclusions}

1. Integral EEG patterns were identified in patients with cerebral hemorrhagic hemispheric stroke, which take into consideration the totality of spectral analysis parameters of spontaneous bioelectric activity of both hemispheres (relative spectral power, intra-hemispheric zone differences, interhemispheric rhythm asymmetry). These types of EEG pattern are associated with the func- tional state of subtentorial structures (Chi-squared $=38.5$, $\mathrm{P}<0.0001)$ and the neuroimaging criteria of midline shift severity (Chi-squared $=21.4, P=0.0001$ ).

2. Bilateral domination of the RSRP $\delta$-range with an accent in $\mathrm{IH}$ in combination with FORG inversion of a-range due to elevation of the $\alpha 2$-subrange in the anterior areas of $\mathrm{IH}$ in patients with SSICH is an informative integral electroencephalographic diagnostic criterion for medium/ severe dysfunction of subtentorial structures (sensitivity $94.7 \%$, specificity $-92.6 \%$ ), whereas ipsilateral increase of RSRP of $\delta$-range with the dominance of $\theta$-range rhythms in slow-wave activity structure in combination with smoothing of zonal differences of $\alpha$-range rhythms in $\mathrm{AH}$ in patients with SSICH the reflects focal lesion of the hemisphere in combination along with the low dysfunction of subtentorial structures or with the absence of the latter.

The perspective for the further scientific research is the research is the elaboration of EEG criteria for the prediction of SSICH acute period outcome.

\section{Funding}

Investigation is funded as a part of scientific research work in Zaporizhzhia state medical university "Optimization of the diagnostic, treatment and rehabilitation approaches in patients with acute and chronic cerebral bloodflow violations", number of state registration 01130000798 (2013-2017).

Conflicts of interest: author has no conflict of interest to declare. Конфлікт інтересів: віАсутній.

Information about author:

Kuznietsov A. A., MD, PhD, Associate Professor of the Department of Nervous Diseases, Zaporizhzhia State Medical University, Ukraine.

Відомості про автора:

Кузнєцов А. А., канА. меА. наук, Аоцент каф. нервових хвороб, Запорізький Аержавний меАичний університет, Україна.

\section{Сведения об авторе:}

Кузнецов А. А., канА. меА. наук, Аоцент каф. нервных болезней, Запорожский государственный медицинский университет, Украина.

Надійшла Ао редакції / Received: 25.09.2018

Після Аоопрацювання / Revised: 12.10.2018

Прийнято Ао Аруку / Accepted: 17.10.2018

\section{References}

[1] Chernii, T. V. (2014) Nejrofiziologicheskaya traktovka E'E'G-fenomenologii $v$ ocenke funkcional'nykh narushenij pri tyazhelykh povrezhdeniyakh golovnogo mozga [Neurophysiological explanation of EEG-fenomenon in the estimation of functional disorders due to severe brain injury]. Zhurnal nevrolohii im. B. M. Mankovskoho, 3, 81-91. [in Russian]

[2] Cherniy, V. I., Andronova, I. A., Gorodnik, G. A., Nazarenko, K. V., \& Cherniy, O. V. (2016) Issledovanie E'E'G--prediktorov nejromediatornoj i nejroglial'noj aktivnosti, osobennostej perestrojki mezhcentral'nykh otnoshenij mozga u pacientov s tyazheloj cherepno-mozgovoj travmo [The research of EEG predictors of neurotransmitter and neuroglial activity, the features of restructuring the brain intracentral relations in patients with severe TBI]. Mizhnarodnyi nevrolohichnyi zhurnal, 5, 41-54. [in Russian]. doi: 10.22141/2224-0713.5.83.2016.78470.

[3] Assenza, G., Zappasodi, F., Pasqualetti, P., Vernieri, F., \& Tecchio, F. (2013). A contralesional EEG power increase mediated by interhemispheric disconnection provides negative prognosis in acute stroke. Restor Neurol Neurosci, 31(2), 177-188. doi: 10.3233/RNN-120244. 
[4] Agius Anastasi, A., Falzon, O., Camilleri, K., Vella, M., \& Muscat, R. (2017) Brain Symmetry Index in Healthy and Stroke Patients for Assessment and Prognosis. Stroke Res Treat, 2017. https://doi. org/10.1155/2017/8276136.

[5] Bentes, C., Peralta, A. R., Viana, P., Martins, H., Morgado, C., Casimiro, C., et al. (2018) Quantitative EEG and functional outcome following acute ischemic stroke. Clin Neurophysiol., 129(8), 1680-1687. doi: 10.1016/j.clinph.2018.05.021.

[6] Chen, Y., Xu, W., Wang, L., Yin, X., Cao, J., Deng, F., et al. (2018) Transcranial Doppler combined with quantitative EEG brain function monitoring and outcome prediction in patients with severe acute intracerebral hemorrhage. Crit Care, 22, 36. doi: [10.1186/s13054-018-1951-y].

[7] Diedler, J., Sykora, M., Bast, T., Poli, S., Veltkamp, R., Mellado, P., et al. (2009). Quantitative EEG correlates of low cerebral perfusion in severe stroke. Neurocrit Care, 11(2), 210-216. doi: 10.1007/s12028009-9236-6.

[8] Fiorella, D., Zuckerman, S. L., Khan, I. S., Ganesh Kumar, N., \& Mocco, J. (2015) Intracerebral Hemorrhage: A Common and Devastating Disease in Need of Better Treatment. World Neurosurg, 84(4), 1136-1141. doi: 10.1016/j.wneu.2015.05.063.

[9] Li, J., Shalabi, A., Ji, F., \& Meng, L. (2017). Monitoring cerebral ischemia during carotid endarterectomy and stenting. J Biomed Res, 31, 11-16. doi: 10.7555/JBR.31.20150171.

[10] Finnigan, S. P., Walsh, M., Rose, S. E., \& Chalk, J. B. (2007). Quantitative EEG indices of sub-acute ischaemic stroke correlate with clinical outcomes. Clin Neurophysiol, 118(11), 2525-2532. doi: 10.1016/j. clinph.2007.07.021.

[11] Kirkman, M. A., \& Smith, M. (2013) Supratentorial intracerebral hemorrhage: a review of the underlying pathophysiology and its relevance for multimodality neuromonitoring in neurointensive care. J Neurosurg Anesthesiol, 25(3), 228-239. doi: 10.1097/ANA.0b013e3182836059.

[12] Purandare, M., Ehlert, A. N., Vaitkevicius, H., Dworetzky, B. A., \& Lee, J. W. (2018) The role of CEEG as a predictor of patient outcome and survival in patients with intraparenchymal hemorrhages. Seizure, 61, 122-127. doi: 10.1016/j.seizure.2018.08.014.

[13] Sheorajpanday, R. V., Nagels, G., Weeren, A. J., De Surgeloose, D., \& De Deyn, P. P. (2010). Additional value of quantitative EEG in acute anterior circulation syndrome of presumed ischemic origin. Clin Neurophysiol, 121(10), 1719-1725. doi: 10.1016/j.clinph.2009.10.037.

[14] Sheorajpanday, R. V., Nagels, G., Weeren, A. J., van Putten, M. J., \& De Deyn, P. P. (2011). Quantitative EEG in ischemic stroke: correlation with functional status after 6 months. Clin Neurophysiol, 122(5), 874-883. doi: 10.1016/j.clinph.2010.07.028.

[15] Schreuder, F. H., Sato, S., Klijn, C. J., \& Anderson, C. S. (2017) Medical management of intracerebral haemorrhage. J Neurol Neurosurg Psychiatry, 88(1), 76-84. doi: 10.1136/jnnp-2016-314386.

[16] van Putten, M. J., \& Hofmeijer, J. (2016). EEG Monitoring in Cerebral Ischemia: Basic Concepts and Clinical Applications. J Clin Neurophysiol, 33(3), 203-210. doi: 10.1097/WNP.0000000000000272.

[17] Xin, X., Chang, J., Gao, Y., \& Shi, Y. (2017). Correlation Between the Revised Brain Symmetry Index, an EEG Feature Index, and Shortterm Prognosis in Acute Ischemic Stroke. J Clin Neurophysiol, 34(2), 162-167. doi: 10.1097/WNP.0000000000000341.

[18] Xu, P., Scalzo, F., Bergsneider, M., Vespa, P., Chad, M., \& Hu, X. (2008) Wavelet entropy characterization of elevated intracranial pressure. Conf Proc IEEE Eng Med Biol Soc, 2008, 2924-2927. doi: 10.1109/ IEMBS.2008.4649815.

[19] Wolf, M. E., Ebert, A. D., \& Chatzikonstantinou, A. (2017). The use of routine EEG in acute ischemic stroke patients without seizures: generalized but not focal EEG pathology is associated with clinical deterioration. Int J Neurosci, 127(5), 421-426. doi: 10.1080/002074 54.2016 .1189913

[20] Wu, J., Srinivasan, R., Burke Quinlan, E., Solodkin, A., Small, S. L., \& Cramer, S. C. (2016) Utility of EEG measures of brain function in patients with acute stroke. J Neurophysiol, 115(5), 2399-2405. doi: 10.1152/jn.00978.2015. 